Research Article

\title{
Classification and Disintegration Characteristics of the Carboniferous Rocks in Guangxi, China
}

\author{
Peng Mo, ${ }^{1}$ Junhui Luo $\mathbb{D},{ }^{1,2}$ Decai Mi, ${ }^{2}$ Zhenchao Chang $\left(\mathbb{D},{ }^{1}\right.$ Haifeng Huang, ${ }^{1}$ Tao Zhang, \\ Guanhua Sun, ${ }^{4}$ Yan $\mathrm{Li}^{4}{ }^{4}$ Ling Zeng $\mathbb{D}^{5},{ }^{5}$ and Shihai Wang ${ }^{1}{ }^{1}$ \\ ${ }^{1}$ Guangxi Beitou Transportation Maintenance Technology Group Co., Ltd., Nanning, Guangxi 530029, China \\ ${ }^{2}$ Guangxi Communication Design Group Co., Ltd., Nanning, Guangxi 530029, China \\ ${ }^{3}$ Faculty of Engineering, China University of Geosciences, Wuhan 430074, China \\ ${ }^{4}$ State Key Laboratory of Geomechanics and Geotechnical Engineering, Institute of Rock and Soil Mechanics, \\ Chinese Academy of Sciences, Wuhan, Hubei 430071, China \\ ${ }^{5}$ School of Civil Engineering, Changsha University of Science \& Technology, Changsha 410114, China \\ Correspondence should be addressed to Shihai Wang; wangsh214@126.com
}

Received 22 August 2021; Revised 16 October 2021; Accepted 25 October 2021; Published 19 November 2021

Academic Editor: Xiaohu Zhang

Copyright (c) 2021 Peng Mo et al. This is an open access article distributed under the Creative Commons Attribution License, which permits unrestricted use, distribution, and reproduction in any medium, provided the original work is properly cited.

To investigate the disintegration characteristics of the carbonaceous rocks in Guangxi Province, the typical carbonaceous rocks in the section exposed by the Hechi-Baise Expressway were investigated in this study. First, based on their mineral compositions and contents, the carbonaceous rocks were divided into four types: carbonate chert, carbonaceous argillaceous limestone, carbonaceous illite clay mudstone, and carbonaceous illite clay shale. Then, through indoor wet-dry cyclic disintegration test, the disintegration characteristics of the four types of rocks were studied. The test results showed the following: (1) the disintegration residues of the carbonate chert and the carbonaceous argillaceous limestone decrease linearly as the number of wetting-drying cycles increases. (2) The disintegration index of the carbonaceous illite clay mudstone and the carbonaceous illite clay shale decreases exponentially as the number of wetting-drying cycles increases. (3) As the number of wetting-drying cycles increases, the disintegration index curves of the carbonaceous illite clay mudstone and the carbonaceous illite clay shale samples gradually become stable until the disintegration of the samples is completed. (4) The disintegration of carbonaceous rocks is mainly affected by the clay content, followed by the structural form, but it cannot be ignored.

\section{Introduction}

Carbonaceous rocks are normally defined as hand-soiling black or grayish black claystones containing large quantities of carbonized organic matter as a result of tectonic or sedimentary processes. Carbonaceous rocks are widely found throughout China, particularly in Guangxi, Guizhou, and Yunnan provinces [1]. Its unique geographical location and extensive tectonic and sedimentary history account for the complicated tectonic conditions in Guangxi Province, where carbonaceous rocks have been exposed by many road and bridge construction projects over the past years. Some of the examples include the construction sections along the Liuzhai-Renshui Secondary Highway, the Shuiren-Nanning
Expressway, the Yizhou-Liuzhai Expressway, the LiuzhaiHechi Expressway, the Hechi-Baise Primary Expressway, the Jinchengjiang-Yizhou Primary Highway, and the YizhouLiuzhou Expressway. Despite their distinct regional physical properties and mineral contents, the carbonaceous rocks in Guangxi Province are quite similar in terms of their engineering characteristics. Typically, these engineering characteristics include a high initial strength, low weathering and slake durability, vulnerability to disturbance, complicated mineral compositions, and unsuitability for plant growth [2].

Sensitive to the natural environment, easy to shatter, disintegrate, and soften, carbonaceous rock generally refers to a particular clay rock whose engineering properties 
change greater along with the natural environment $[3,4]$. In Guangxi, the distribution of carbonaceous rock is not as widely as red clay. However, landslides, collapse, and other geological disasters often occur on the highway and railway slopes composed of carbonaceous rock, attracting the attention of various industries $[5,6]$. It is well known that failure modes of carbonaceous rock slopes include two categories. The first kind mainly occurs in bedding sliding, the sliding deformation of the upper loose overburden along with the rock, and soil interface after the slope excavation. The second type is the collapse of surface rock mass caused by the changes of its properties after slope excavation, generally manifested as the spalling and disintegration of a surface rock mass $[7,8]$. After the carbonaceous rock slope is excavated and exposed, the carbonaceous rock is prone to softening and collapse under the action of water immersion, resulting in slope collapse and affecting the stability of the slope (Figure 1). At present, the research on carbonaceous rocks mainly focuses on the material composition, structural characteristics, mineralized composition, physical and mechanical properties as well as deformation and failure mechanism, etc. Therefore, it is of greater significance to understand the softening and disintegration of carbonaceous rocks by carrying out relevant laboratory tests.

Rock slaking behavior has been widely studied all over the world. Gamble et al. $[9,10]$ deemed that one factor alone can hardly cause extensive slaking of carbonaceous mudstones. Instead, this is a process jointly controlled by temperature, humidity, and several other factors. Based on slaking tests on soft rock samples, Qu [11] concluded that the slaking rate of soft rocks is related not only to the mineral contents of the rocks but also to the degree of cementation of the rocks. Zhang et al. [12] deemed that the expansibility of these rocks is inversely correlated with the grain sizes of the fraction with the maximum content, effective grain size, and slake durability index of the collapsed scraps of the swelling rock. Liang et al. [13] investigated the changes in the morphology, static disintegration index, and disintegration ratio of four different kinds of soft rocks under slaking based on their mineral compositions and physical parameters. Guo et al. [14] carried out laboratory wetting and disintegration tests on typical red mudstone samples under different conditions. The results revealed that the moisture content during the wetting-drying cycles was the driving factor behind the disintegration of soft red mudstone. Surendra [15] examined the effects of the mineral composition on shale durability and suggested using inorganic salt modifiers to control the slaking of soft rocks. Nara et al. [16] studied the influences of temperature and humidity on subcritical crack growth in sandstone. Bailey [17] analyzed the particle degradation of soft rocks during compaction in subgrade construction. However, previous studies on rock slake durability have mainly focused on soft rocks, with less attention paid to the slaking behavior of carbonaceous rocks.

In view of this, investigating the slaking behavior of the carbonaceous rocks in Guangxi Province is of both engineering and theoretical significance.

\section{Classification of the Carbonaceous Rocks in Guangxi Province}

In engineering practice, hand-soiling rocks containing large quantities of dispersed carbonized organic matter are often collectively called carbonaceous rocks, which we do not think is appropriate because carbonaceous rocks containing different mineral components differ in terms of their physical-chemical properties, strengths, and slaking behaviors. Whole-rock mineral analysis and clay mineral quantification were conducted on carbonaceous rock samples from the Hechi-Baise Expressway (HBE) using powder $\mathrm{X}$-ray diffraction (XRD, Figure 2).

To classify the carbonaceous rock samples from the HBE, first, the mineral compositions of these samples were investigated. The carbonaceous rock outcroppings at stakes K19-K22 were sampled and prepared (ground) for X-ray diffraction analysis (Figures 3 and 4). Table 1 lists the main mineral components and their percentage contents in the samples.

As shown in Table 1, the mineral contents of samples A1 and $\mathrm{A} 2$ are quartz, calcite, and a trace amount of dolostone, with quartz accounting for $69.63 \%$ and calcite accounting for $28.66 \%$. Neither of these samples contains clay minerals. The main mineral contents of samples A3, B2, C2, and C3 are calcite, quartz, illite, and a lesser amount of pyrite, with calcite accounting for $43.30 \%-66.06 \%$ and quartz accounting for $5.90 \%-37.74 \%$. In addition, the clay minerals, which are primarily illite, account for approximately $10 \%$. Smectite was found in some of the samples, and the pyrite contents of all of these samples are less than $2.30 \%$. The main mineral contents of samples $\mathrm{C} 4, \mathrm{C} 5, \mathrm{D}, \mathrm{E}, \mathrm{F}$, and $\mathrm{H}$ are quartz, calcite, dolostone, illite, and pyrite, with quartz accounting for $45.69 \%-$ $64.31 \%$. Clay minerals, which are primarily illite, account for $20.65 \%-27.18 \%$, and dolostone accounts for $7.12 \%-15.13 \%$. Some of these samples contain calcite, which accounts for a maximum of $17.92 \%$, and a minimal amount of pyrite, which accounts for a maximum of $2.64 \%$.

Based on the mineral components and their percentage contents in the carbonaceous rock samples from the HBE, the main clay mineral in the carbonaceous rocks is illite, which generally accounts for less than $24.74 \%$. Smectite is also present in a few of the rock samples. Except for sample $\mathrm{B}$, all of the other samples have high quartz contents. Some of the samples contain small amounts of dolostone, pyrite, and other minerals.

Considering the external characteristics, mineral compositions, and contents of the rock samples, according to the Classification and Nomenclature Schemes of Sedimentary Rock (GB-T17412.2-1998), the rock samples from the HBE are named as follows:

(i) Samples A1 and A2 are carbonate-bearing cherts

(ii) Samples A3, B2, C2, and C3 are carbonaceous mudbearing limestones

(iii) Samples C4, C5, and D are carbonaceous illite claystones

(iv) Samples E, F, and H are carbonaceous illite clay shales 


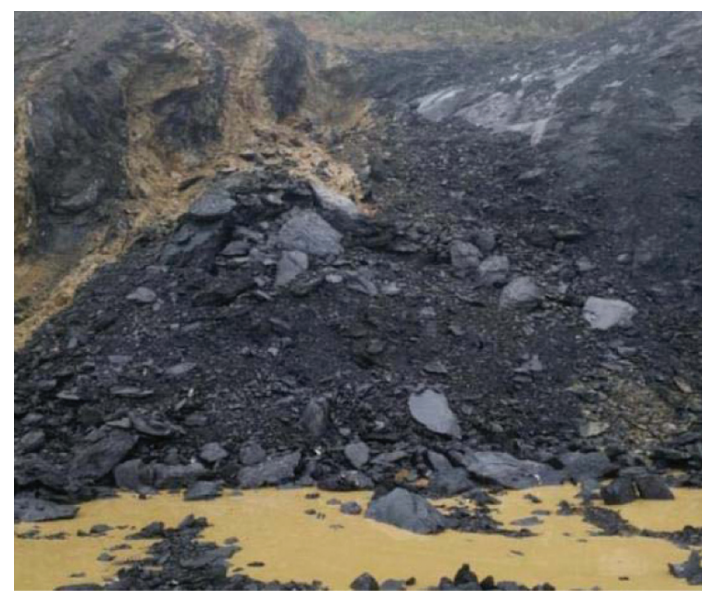

Figure 1: Carbonaceous rock slope collapses.

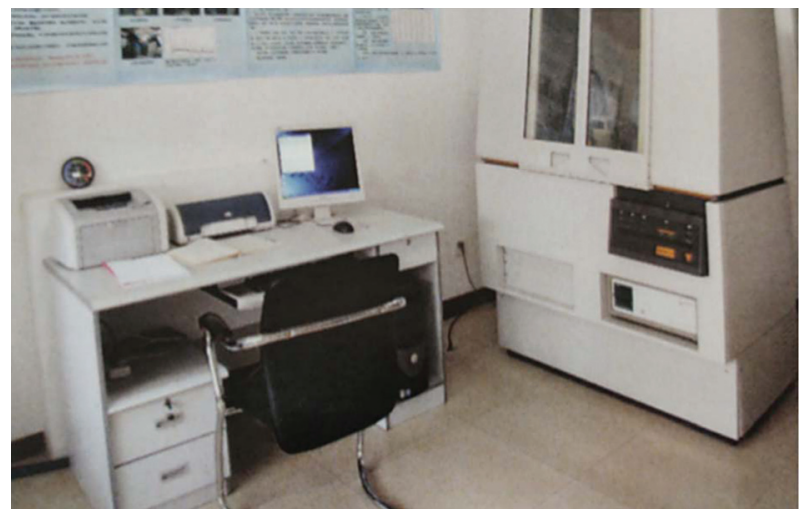

Figure 2: Advance X-ray diffraction machine.

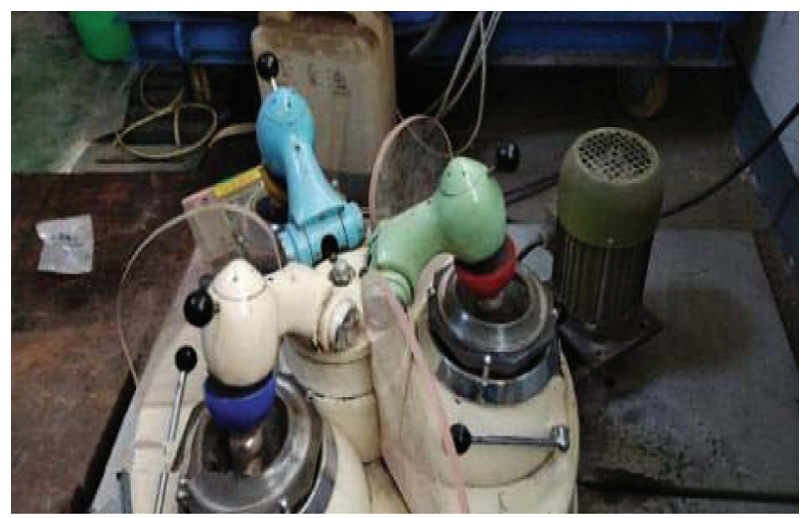

FIGURE 3: Carbonaceous rock sample grinding process from Hebailu.

To facilitate discrimination during the subsequent experiments, the carbonaceous mud-bearing limestone samples were renumbered B1, B2, B3, and B4; the carbonaceous

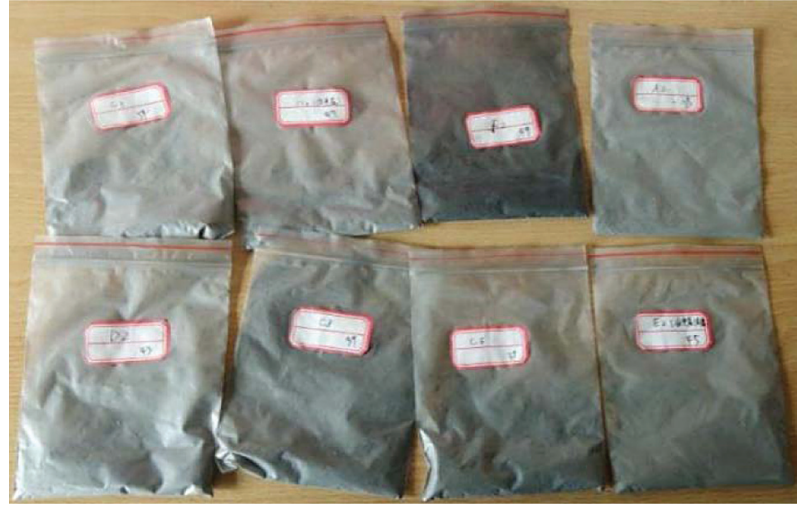

Figure 4: Partial sample after grinding.

illite claystone samples were renumbered $\mathrm{C} 1, \mathrm{C} 2$, and $\mathrm{C} 3$; and the other samples were not renumbered.

\section{Slake Durability Testing of the Carbonaceous Rocks in Guangxi Province}

To establish the slake durability of the carbonaceous rock samples from the HBE, laboratory slaking tests were conducted on the samples under wetting-drying cycles according to the recommendations of the Standard for Tests Method of Engineering Rock Masses (GB/T 50266-2013) for the slake durability testing of rocks.

3.1. Test Equipment. Oven: an LY-660 precision industrial thermostatic air-dry oven was used (Figure 5). In our experiment, the drying temperature was maintained at approximately $105^{\circ} \mathrm{C}$, as recommended by the standard. (2) Slake durability apparatus: the disintegrating tester at the Institute of Rock and Soil Mechanics, Chinese Academy of Sciences, was used (Figure 6). During operation, the speed of the apparatus was maintained at $20 \mathrm{r} / \mathrm{min}$. The cylindrical screen drum is $100 \mathrm{~mm}$ (long) by $140 \mathrm{~mm}$ (diameter), with a mesh diameter of $2 \mathrm{~mm}$. (3) Double-face rock grinder: an SCM-200 double-face rock grinder was used. The automatic grinding feed rate was $0.04-0.12 \mathrm{~mm}$. In addition to these apparatus, electronic balances (with a precision of $0.01 \mathrm{~g}$ ) and thermometers were also used as needed.

3.2. Sample Preparation. The rock samples were collected from the HBE and sealed with industrial parafilm (Figure 7). Then, the samples were placed in a plastic wrap to preserve their natural moisture content. The rock samples were reshaped into a rounded form. The mass of each of the specimens was maintained at $40-60 \mathrm{~g}$ using the rock grinder. Each specimen group contained at least 10 specimens (Figure 8). All four types of carbonaceous rocks were prepared into specimens and were tested separately. 
TABLE 1: Main mineral compositions and percentage contents of the carboniferous rocks.

\begin{tabular}{|c|c|c|c|c|c|c|c|c|}
\hline \multirow{2}{*}{ Sample number } & \multicolumn{8}{|c|}{ Mineral content (\%) } \\
\hline & Quartz & Calcite & Dolomite & Illite & Montmorillonite & Kaolinite & Chlorite & Pyrite \\
\hline A1 & 69.93 & 28.66 & 1.41 & - & - & - & - & - \\
\hline A2 & 75.41 & 23.05 & 1.55 & - & - & - & - & - \\
\hline A3 (B1) & 37.74 & 45.91 & 2.82 & 11.24 & - & - & - & 2.3 \\
\hline B2 & 28.55 & 58.85 & - & 12.60 & - & - & 15.53 & - \\
\hline C2 (B3) & 5.9 & 66.06 & - & 11.44 & 15.01 & - & - & 1.59 \\
\hline C3 (B4) & 27.68 & 43.30 & 7.06 & 10.67 & 9.92 & - & - & 1.37 \\
\hline $\mathrm{C} 4(\mathrm{C} 1)$ & 45.69 & 6.93 & 11.97 & 24.74 & - & - & 8.03 & 2.64 \\
\hline C5 (C2) & 45.84 & 17.92 & 11.42 & 22.62 & - & - & - & - \\
\hline $\mathrm{D}(\mathrm{C} 3)$ & 52.31 & 15.63 & 9.73 & 20.65 & - & - & - & 1.69 \\
\hline $\mathrm{E}$ & 64.31 & - & 15.13 & 21.74 & - & - & - & - \\
\hline F & 57.26 & 12.09 & 8.43 & 22.22 & - & - & - & 2.20 \\
\hline $\mathrm{H}$ & 62.02 & - & 7.12 & 27.18 & 3.69 & - & - & - \\
\hline
\end{tabular}

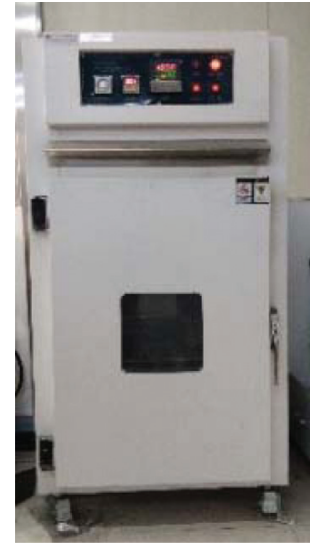

Figure 5: Oven.

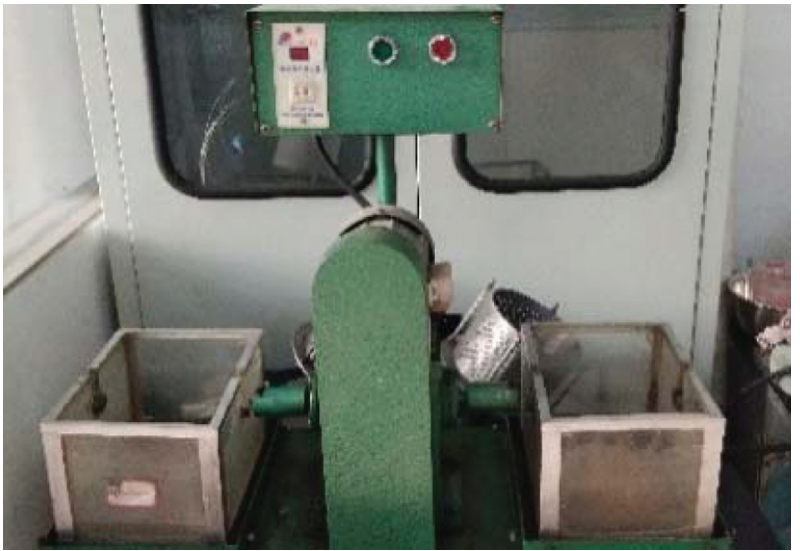

FIGURE 6: Disintegrating tester.

3.3. Test Procedure. First, the screen drum was dried and weighed. Next, the rock specimen was placed into the screen drum and dried at $105^{\circ} \mathrm{C}-110^{\circ} \mathrm{C}$ for $24 \mathrm{~h}$. Then, the screen drum with the rock specimen was taken out of the oven and placed into the dryer to cool to room temperature before it was weighed again.

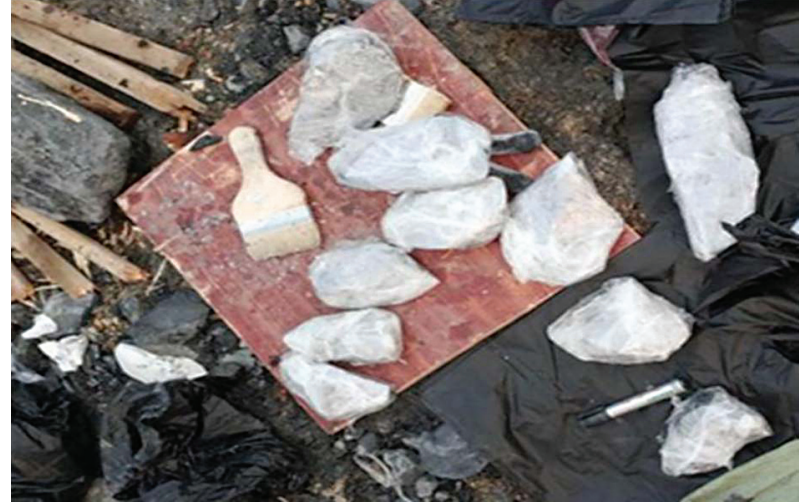

Figure 7: Wax-sealed field rock samples.

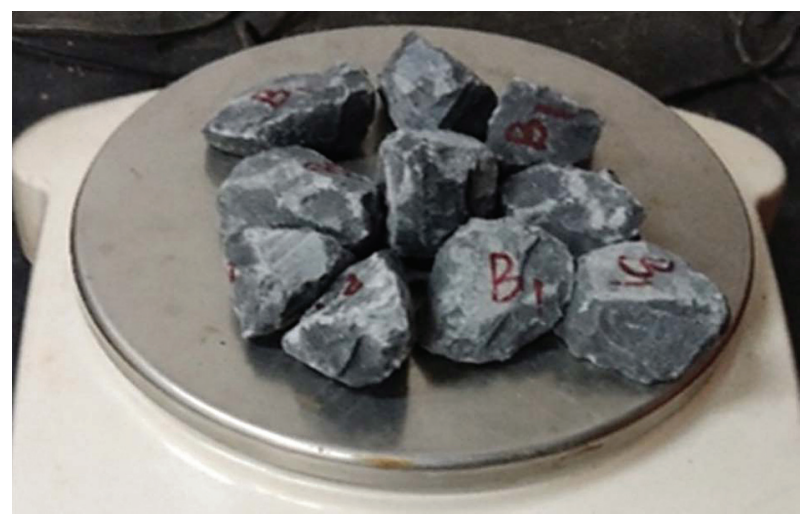

FIGURE 8: Disintegrating test samples.

The screen drum with the rock specimen was placed in the water flume. Then, distilled water was poured into the flume to approximately $20 \mathrm{~mm}$ below the rotary shaft. The slake durability apparatus was started. The screen drum was run at a constant velocity of $20 \mathrm{r} / \mathrm{min}$ for $10 \mathrm{~min}$, and then, the screen drum with the residual specimen was dried in the oven at $105^{\circ} \mathrm{C}-110^{\circ} \mathrm{C}$ for $24 \mathrm{~h}$ to a constant mass, cooled in the dryer to room temperature, and weighed. The second 
step was repeated for the number of cycles required by the experiment, and the experimental data were recorded. The water temperature was maintained at $20^{\circ} \mathrm{C} \pm 2^{\circ} \mathrm{C}$ during the experiment. At the end of the experiment, the colors of the residual specimen and the water and the characteristics of any precipitate left in the water were described.

3.4. Results and Analysis. The rock slake durability index was calculated using the following equation:

$$
I_{d i}=\frac{m_{r}}{m_{s}} \times 100
$$

where $I_{d i}$ is the slake durability index of the rock after the $i$ th wetting-drying cycle (\%); $m_{s}$ is the dried mass of the original sample (g); and $m_{r}$ is the dried mass of the residual specimen (g).

The rock slake durability index is defined as the mass percentage after each standard wetting-drying cycle relative to the mass of the previous cycle:

$$
I_{d i}=\frac{m_{i}}{m_{i-1}} \times 100
$$

where $I_{d i}$ is the slake durability index of the rock after the $i$ th wetting-drying cycle (\%); $m_{i}$ is the mass of the residue after the $i$ th standard wetting-drying cycle $(\mathrm{g})$; and $m_{i-1}$ is the mass of the residue after the $(i-1)$ th standard wettingdrying cycle $(\mathrm{g})$.

3.4.1. Slake Durability Indexes of the Carbonaceous Rocks. Separate slaking tests were conducted on the different types of carbonaceous rock samples from the HBE. Each type was tested under six wetting-drying cycles, and their respective slake durability indexes were obtained. Tables 2 and 3 present the slake durability indexes of the rock samples. To facilitate observation, the data in these tables are also plotted in Figures 9 and 10.

From Figures 9 and 10, for the carbonate-bearing cherts (A1 and A2) and the carbonaceous mud-bearing limestones (B1, B2, B3, and B4), after six standard wetting-drying cycles, the slaking residues and slake durability indexes were linearly related to the number of cycles in all cases. The slake durability indexes remained higher than $90 \%$ after six wetting-drying cycles.

The slaking of both types of rocks (i.e., the mass reduction of the samples after the experiment) can be understood as a uniform mass reduction of the carbonatebearing chert or carbonaceous mud-bearing limestone resulting from water erosion of the sample and the centrifugal pull from the rotation of the screen drum under laboratory wetting-drying cycles. The relationship between the residual mass of a specimen and the number of wettingdrying cycles is fitted by the following linear equations:

$$
\begin{aligned}
& A 1: y=-4.5729 x+391.33, \\
& A 2: y=-1.3786 x+472.95,
\end{aligned}
$$

TABLE 2: Residual mass of each disintegration for the rock samples from Hebailu.

\begin{tabular}{lccccccc}
\hline \multirow{2}{*}{$\begin{array}{l}\text { Sample } \\
\text { number }\end{array}$} & 0 & 1 & 2 & 3 & 4 & 5 & 6 \\
\hline A1 & 392.24 & 385.94 & 381.97 & 377.84 & 372.41 & 368.52 & 364.36 \\
A2 & 473.82 & 470.97 & 469.86 & 468.38 & 467.54 & 466.27 & 464.86 \\
B1 & 297.50 & 296.58 & 291.71 & 288.60 & 287.00 & 283.30 & 281.43 \\
B2 & 592.34 & 588.26 & 584.07 & 574.32 & 561.47 & 550.25 & 542.10 \\
B3 & 488.22 & 483.40 & 480.00 & 476.19 & 474.52 & 472.37 & 469.95 \\
B4 & 374.07 & 371.25 & 367.10 & 363.68 & 360.44 & 357.25 & 353.75 \\
C1 & 416.16 & 386.6 & 343.32 & 282.8 & 262.68 & 247.25 & 234.01 \\
C2 & 379.40 & 343.85 & 291.08 & 213.85 & 190.10 & 180.24 & 162.34 \\
C3 & 446.94 & 382.44 & 290.29 & 225.71 & 192.67 & 171.08 & 154.75 \\
E & 478.89 & 464.31 & 430.25 & 380.10 & 354.17 & 332.55 & 318.97 \\
F & 479.88 & 461.20 & 441.62 & 420.28 & 399.19 & 368.65 & 342.87 \\
H & 356.90 & 354.59 & 346.62 & 324.62 & 308.75 & 294.60 & 282.03 \\
\hline
\end{tabular}

TABLE 3: Disintegration resistance index of the Hebailu rock samples.

\begin{tabular}{lccccccc}
\hline \multirow{2}{*}{ Sample number } & \multicolumn{6}{c}{ Disintegration resistance index (\%) } \\
& $I_{\mathrm{d} 0}$ & $I_{\mathrm{d} 1}$ & $I_{\mathrm{d} 2}$ & $I_{\mathrm{d} 3}$ & $I_{\mathrm{d} 4}$ & $I_{\mathrm{d} 5}$ & $I_{\mathrm{d} 6}$ \\
\hline A1 & 100 & 98.39 & 97.38 & 96.33 & 94.94 & 93.95 & 92.89 \\
A2 & 100 & 99.40 & 99.16 & 98.85 & 98.67 & 98.41 & 98.11 \\
$\mathrm{~B} 1$ & 100 & 99.69 & 98.05 & 97.01 & 96.47 & 95.23 & 94.60 \\
$\mathrm{~B} 2$ & 100 & 99.31 & 98.60 & 96.96 & 94.79 & 92.89 & 91.52 \\
$\mathrm{~B} 3$ & 100 & 99.01 & 98.32 & 97.54 & 97.19 & 96.75 & 96.26 \\
$\mathrm{~B} 4$ & 100 & 99.25 & 98.14 & 97.22 & 96.36 & 95.50 & 94.57 \\
$\mathrm{C} 1$ & 100 & 92.90 & 82.50 & 67.95 & 63.12 & 59.41 & 56.23 \\
$\mathrm{C} 2$ & 100 & 90.63 & 76.72 & 56.37 & 50.12 & 47.51 & 42.79 \\
$\mathrm{C} 3$ & 100 & 85.57 & 64.95 & 50.50 & 43.11 & 38.28 & 34.62 \\
$\mathrm{E}$ & 100 & 96.96 & 89.84 & 79.37 & 73.96 & 69.44 & 66.61 \\
$\mathrm{~F}$ & 100 & 96.11 & 92.03 & 87.58 & 83.19 & 76.82 & 71.45 \\
$\mathrm{H}$ & 100 & 99.35 & 97.12 & 90.96 & 86.51 & 82.54 & 79.02 \\
\hline
\end{tabular}

$$
\begin{aligned}
& \text { B1: } y=-2.8386 x+297.96 \\
& \text { B2: } y=-8.905 x+597.12, \\
& \text { B3: } y=-2.9411 x+486.63 \\
& \text { B4: } y=-3.415 x+374.18
\end{aligned}
$$

where $y$ is the specimen's residual mass after slaking, and $x$ is the number of wetting-drying cycles.

As can be seen from equations (3)-(8), the slaking residual mass of the carbonate-bearing cherts and carbonaceous mud-bearing limestones decreased linearly as the number of laboratory wetting-drying cycles increased. Except for specimen B2 (which had a slightly higher clay mineral content than the other specimens), which showed a mass reduction of 8-9 $\mathrm{g}$ after each wetting-drying cycle, all of the other specimens showed a mass reduction of less than $5 \mathrm{~g}$. More importantly, the specimens showed virtually no cracks on the surface, and all of the specimens remained intact after six laboratory wetting-drying cycles. As such, we can assume that in the natural state, the carbonate-bearing 


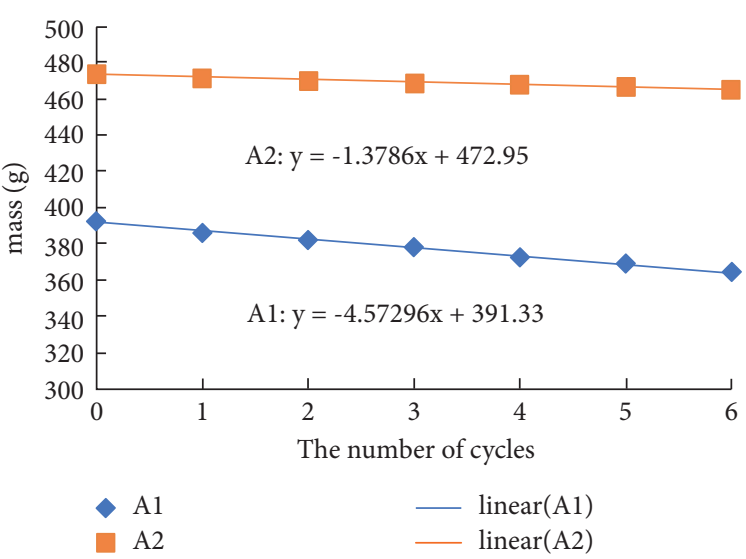

(a)

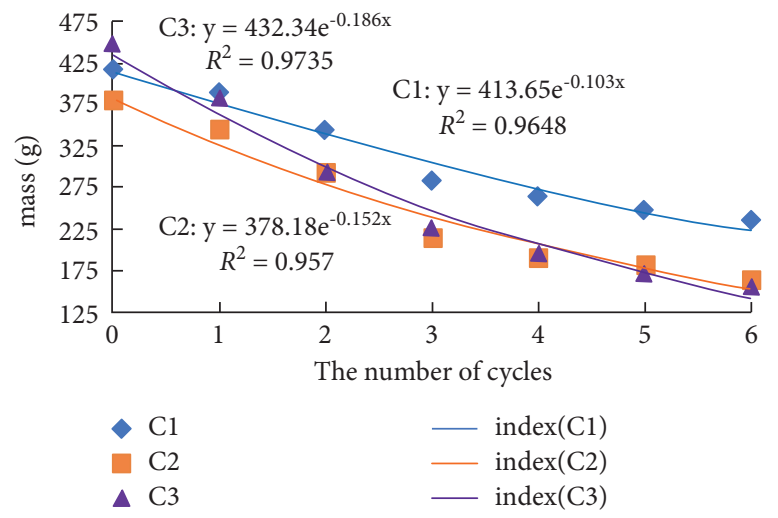

(c)

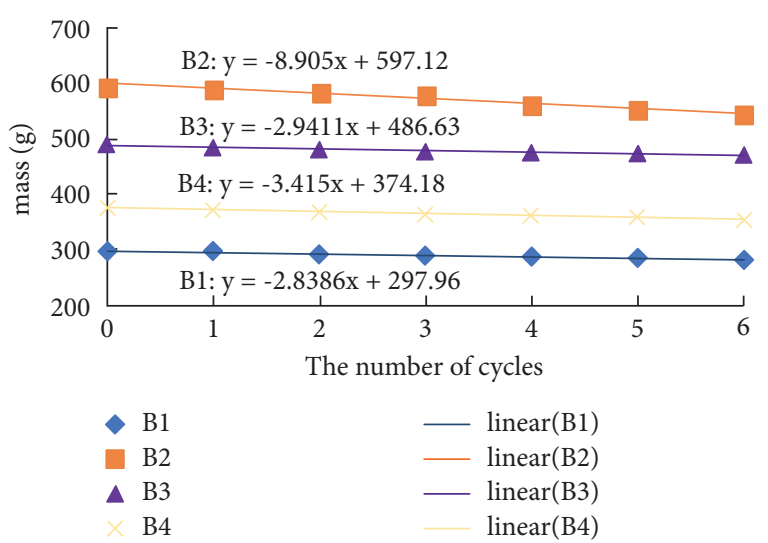

(b)

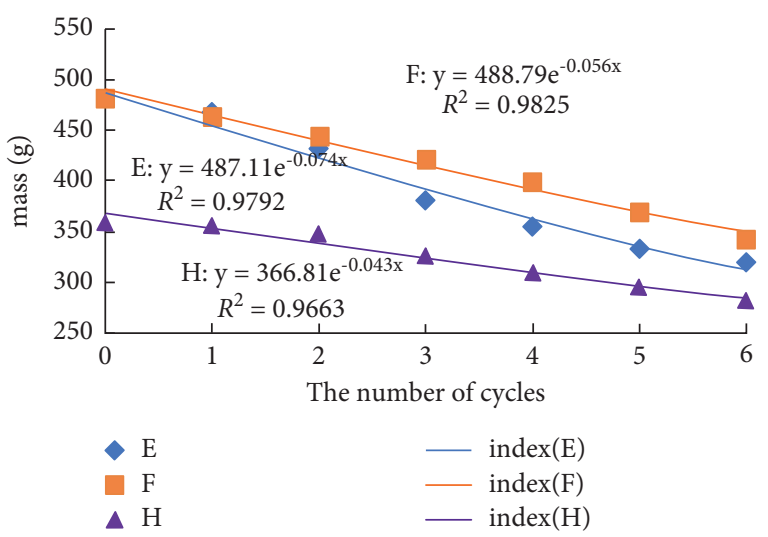

(d)

FIgURE 9: Variation curves of the residual disintegration masses of the four types of carboniferous rocks. (a) Carbonate cherts. (b) Carbonaceous argillaceous limestones. (c) Carbonaceous illite clay mudstones. (d) Carbonaceous illite clay shales.

chert and carbonaceous mud-bearing limestone from the HBE are very weakly slakable or not slakable at all.

In Figure 10, as the number of standard wetting-drying cycles increased, the slake durability index of the carbonaceous illite clay mudstones $(\mathrm{C} 1, \mathrm{C} 2$, and $\mathrm{C} 3)$ and the carbonaceous illite clay shales (E, F, and $\mathrm{H}$ ) from the $\mathrm{HBE}$ gradually decreased, with a $43 \%-66 \%$ reduction for the former and a $21 \%-33 \%$ reduction for the latter. The relationship between the number of standard wetting-drying cycles and the slake durability index of the specimen is fitted by the following equations:

$$
\begin{aligned}
& C 1: y=99.399 e^{-0.103 x}, \\
& C 2: y=99.68 e^{-0.152 x}, \\
& C 3: y=96.736 e^{-0.186 x}, \\
& E: y=101.72 e^{-0.074 x}, \\
& F: y=101.72 e^{-0.056 x},
\end{aligned}
$$

$$
H: y=101.72 e^{-0.043 x} \text {, }
$$

where $y$ is the slake durability index; and $x$ is the number of wetting-drying cycles.

In Figure 11, the specimen's slake durability under different numbers of cycles was close to the fitted curvilinear equation, suggesting that the slake durability of the specimen agrees well with equations (9)-(14), with modest data discretization and very little fluctuation about the curve. Based on the fitting formulas, the slake durability index of the carbonaceous illite clay mudstones and carbonaceous illite clay shales decreased exponentially as the number of wetting-drying cycles increased. Furthermore, as the number of wetting-drying cycles increased, the slake durability index curve gradually flattened until the specimens had completed slaking.

Figure 11 shows the relationship between the slake durability indexes and the number of wetting-drying cycles. As can be seen from this diagram, compared with the carbonaceous illite clay shales, the carbonate-bearing cherts and the mud-bearing limestones are very weakly slakable or not slakable at all. The carbonaceous illite clay shales appear 

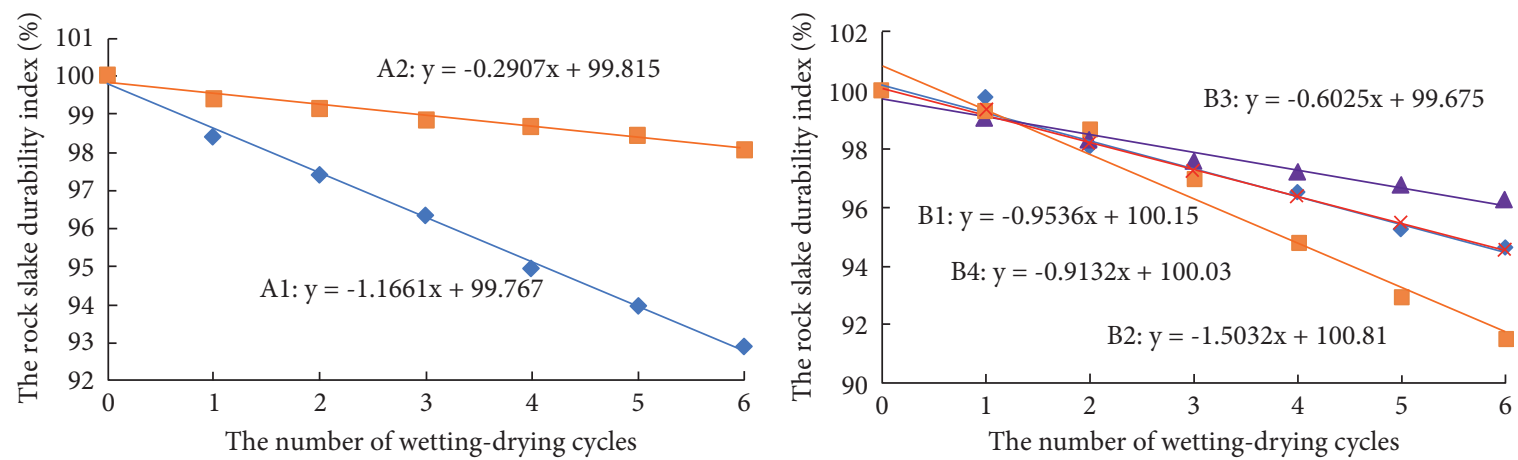

$\begin{array}{ll}\text { A1 } & - \text { linear(A1) } \\ \text { A2 } & \text { linear(A2) }\end{array}$

(a)

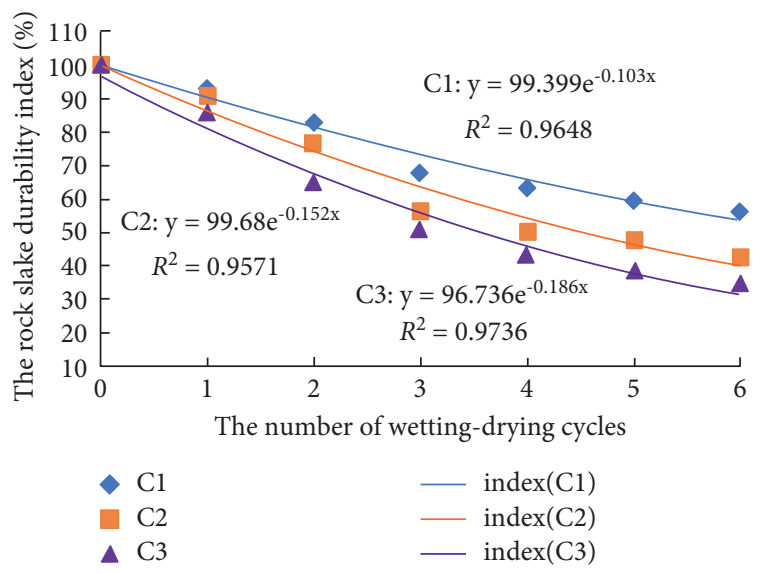

(c)

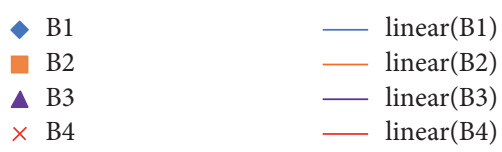

(b)

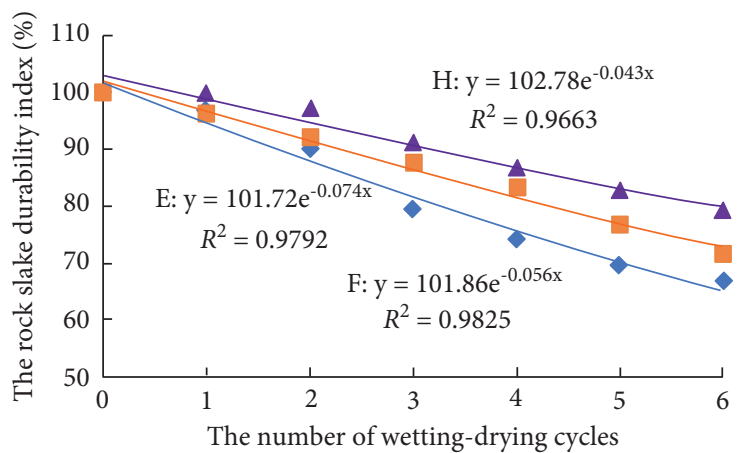

E

F

$\Delta \mathrm{H}$

(d)

FIGURE 10: Relationship curves between the disintegration resistance index and the number of wetting-drying cycles for the carboniferous rocks. (a) Carbonate cherts. (b) Carbonaceous argillaceous limestones. (c) Carbonaceous illite clay mudstones. (d) Carbonaceous illite clay shales.

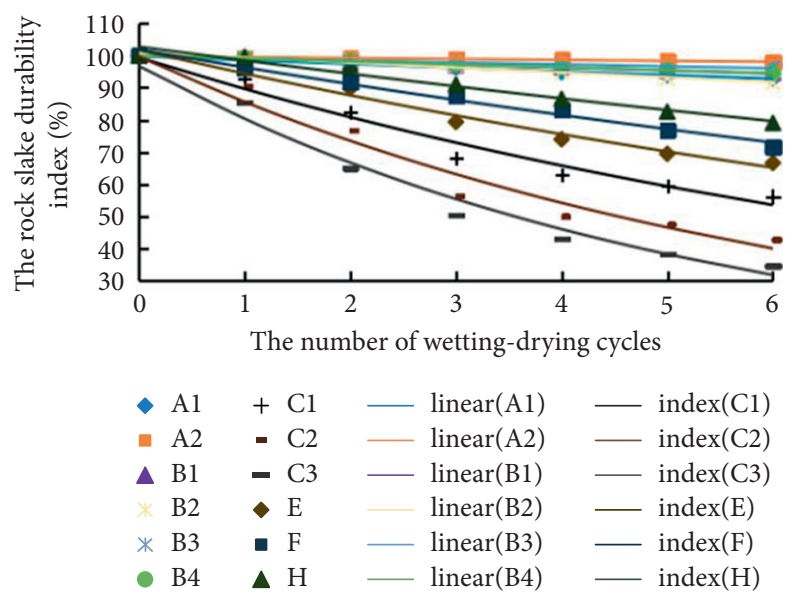

Figure 11: Relationship curves between the disintegration resistance index and the number of wetting-drying cycles for the different carboniferous rocks. 


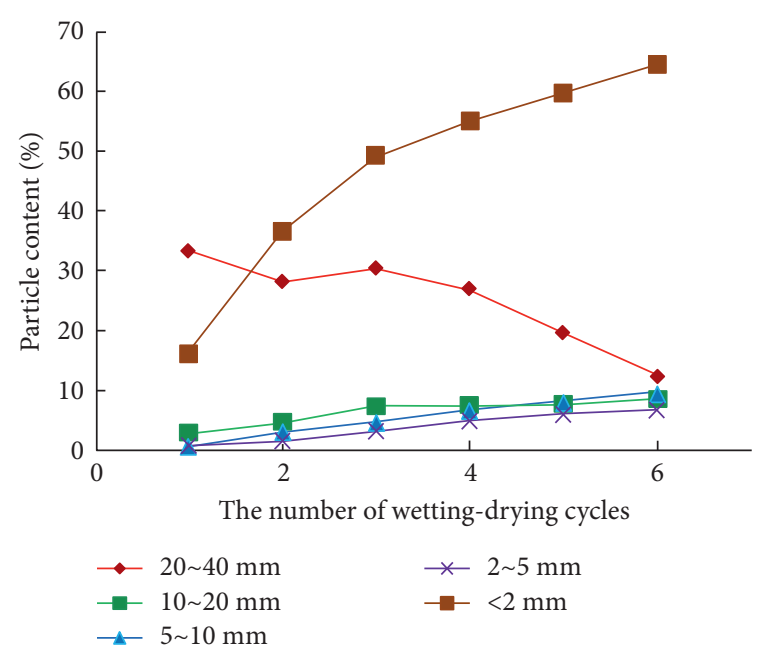

Figure 12: The change in the particle contents of the carbonaceous illite clay mudstones as the number of wetting-drying cycles increases.

to be quite slakable, and the carbonaceous illite mudstones are even more slakable.

3.4.2. Slaking Grain Size Analysis of the Carbonaceous Rocks. Figures 12 and 13 show the dependence of the grain size content of these rocks on the number of wetting-drying cycles. An analysis of these figures reveals the following.

As the number of wetting-drying cycles increased, the content of the $20-40 \mathrm{~mm}$ fraction in the slaking product of the carbonaceous illite clay mudstones gradually decreased, whereas the contents of all of the other grain sizes gradually increased. The content of the $<2 \mathrm{~mm}$ fraction increased the fastest relative to all of the other grain sizes. The slaking product of the carbonaceous illite clay mudstones after the laboratory slaking test was mainly composed of grains $<2 \mathrm{~mm}$.

The carbonaceous illite clay shales were weakly slakable, with a low slaking speed and a lower slakability than the carbonaceous illite clay mudstones. Other than the content of the $<2 \mathrm{~mm}$ fraction, which increased comparatively quickly, the contents of all of the other grain sizes changed slowly, with even smaller variations after the first two cycles. The carbonaceous illite clay shales were less slakable than the carbonaceous illite clay mudstones. The slaking of the carbonaceous illite clay shales typically occurred along the textures, resulting in many schistose structures in the slaking residues that could hardly pass through the smallsize sieve holes. The larger sized grains were the main contributors.

Because the carbonaceous illite clay mudstones were more slakable than the carbonaceous illite clay shales, they slaked noticeably faster than the carbonaceous illite clay shales. The variations in the contents of the larger and smaller grain sizes were also greater. Thus, under the same conditions, the carbonaceous illite clay mudstones required fewer wetting-drying cycles to completely slake compared to the carbonaceous illite clay shales.

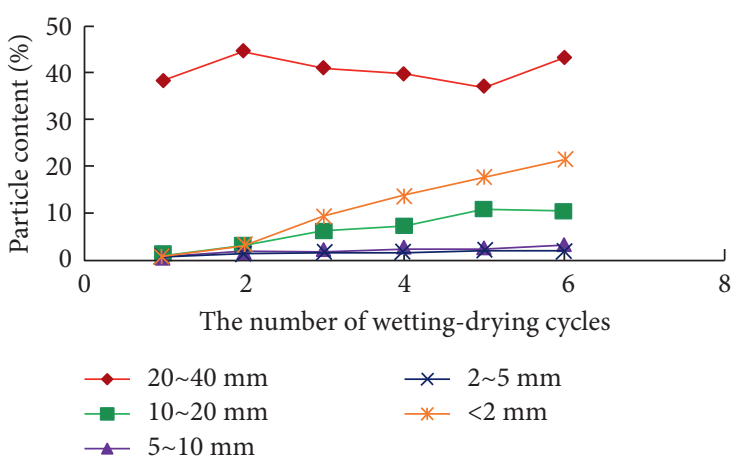

FIgURE 13: The change in the particle contents of the carbonaceous illite clay shales as the number of wetting-drying cycles increases.

\section{Conclusions}

The slaking phenomena and the behaviors of typical outcropping carbonaceous rock in the HBE in Guangxi under different numbers of wetting-drying cycles were investigated through laboratory slaking tests. The residual slaking grains of the rock samples were also analyzed for gradation. The following conclusions were drawn:

(1) As the carbonate-bearing cherts contained no clay minerals and the mud-bearing limestones had a very low clay contents, both rock types appeared to be very weakly slakable or not slakable at all. The carbonaceous illite clay mudstones and carbonaceous illite clay shales, both of which contained more than $20 \%$ clay minerals, were highly slakable. Thus, the clay content constitutes the main driving factor behind the slaking behavior of carbonaceous rocks. Furthermore, despite their similar clay contents, the carbonaceous illite clay mudstones and carbonaceous illite clay shales also differed from each other in terms of their slaking behavior (the carbonaceous illite clay mudstone was more slakable) as a result of their different structural forms. These phenomena suggest that the slaking behavior of the carbonaceous rocks from the HBE was primarily determined by the clay content. The structural form also played a nonnegligible role.

(2) As the number of wetting-drying cycles increased, the grain size contents of the slaking products of the carbonaceous illite clay mudstones and carbonaceous illite clay shales changed continuously, with similarities as well as differences between the two rocks. The carbonaceous illite clay mudstones slaked more quickly. The chunky specimen gradually slaked into smaller fragments and elliptical grains, with the 20-40 mm chunky fraction decreasing quickly, and the $<2 \mathrm{~mm}$ granular fraction increasing quickly. Like the carbonaceous illite clay mudstones, as the number of wetting-drying cycles increased, the $<2 \mathrm{~mm}$ fraction also prevailed in the slaking product of the carbonaceous illite clay shales. The unique stratification of this rock also resulted in the $20-40 \mathrm{~mm}$ schistose fraction predominating in the 
residue, while all of the other grain size fractions increased slowly.

\section{Data Availability}

The data used to support the findings of the study are available from the corresponding author upon request.

\section{Conflicts of Interest}

The authors declare that there are no conflicts of interest regarding the publication of this paper.

\section{Acknowledgments}

This study was supported by the Science and Technology Project of Guangxi "Research on the Key Technologies of Highway Construction in Guangxi Carbonaceous Rock Area" (Grant no. GuikeAC16380119), the "Research and Application of Ecological Slope Protection Technology in Carbonaceous Rock Slopes" (Grant no. AD19110124), and the Key Science and Technology Project of Ministry of Transportation of The People's Government of China "Reinforcement Theory and Technology of Multi-Point Restraint Anchor Cable and Monitoring Warning for Highway High Slope"(Grant no. 2020-MS3-082). The authors thank LetPub (http://www.letpub.com) for its linguistic assistance during the preparation of this manuscript.

\section{References}

[1] J. H. Luo, D. C. Mi, and Q. Y. Ye, "Study on microscopic characteristics and physical and mechanical parameters of carbonaceous rocks," Materials Science Forum, vol. 980, pp. 368-376, 2020.

[2] J. Luo, D. Mi, and H. Huang, "Intelligent monitoring, stability evaluation, and landslide treatment of a carbonaceous mudstone and shale slope in Guangxi, China," International Journal of Safety and Security Engineering, vol. 10, no. 3, pp. 373-379, 2020.

[3] Q. Y. Ye, "Special engineering properties of carbonaceous rocks," Western China Communications Science \& Technology, no. 4, pp. 1-3, 2017.

[4] F. Z. Zhang, X. P. Chen, H. F. Wu et al., "Experimental study on deformation properties and duncan model parameters of soft clayey rocks," Rock and Soil Mechanics, vol. 24, no. 4, pp. 610-613, 2003.

[5] F. Q. Peng, X. Yuan, and H. Yuan, "Research on management and stability analysis of Lou-Xin high-speed complex geological slope," Journal of Railway Science and Engineering, vol. 10, no. 4, pp. 106-111, 2013.

[6] C. Y. Zhou, Y. M. Deng, X. S. Tan, Z. Q. Liu, W. Shang, and S. Zhan, "Experimental research on the softening of mechanical properties of saturated soft rocks and application," Chinese Journal of Rock Mechanics and Engineering, vol. 24, no. 1, pp. 33-38, 2005.

[7] S. Q. Deng, D. Xie, and Z. H. Tang, "Research on failure mode and treatment measures of carbonaceous rock slope," Western China Communications Science \& Technology, no. 6, pp. 1012, 2014.
[8] D. Stead, "The influence of shales on slope instability," Rock Mechanics and Rock Engineering, vol. 49, no. 2, pp. 635-651, 2016.

[9] J. C. Gamble, Durability Plasticity Classification of Mudstones and Other Argillaceous Rock, University of Illinois, IL, USA, 1971.

[10] H. Yamaguchi, Y. Yoshida, I. Kuroshima, and M. Fukuda, "Slaking and shear properties of mudstone," in Proceedings of the ISRM International Symposium, pp. 133-144, International Society for Rock Mechanics and Rock Engineering, Madrid, Spain, September 1988.

[11] Y. X. Qu, "Engineering Geological Study on Argillaceous Cementation in Eastern China," Engineering Geomechanics Open Research experiment 1991 Annual Report, Seismological press, Beijing, China, 1992.

[12] W. Zhang, Y. J. Shang, Y. X. Qu, Y. C. Sun, D. M. Lin, and K. Y. Wang, "Grain size distribution of collapsed scraps of argillaceous rock and its relationship with expansibility: an experimental study," Rock and Soil Mechanics, vol. 34, pp. 66-72, 2013.

[13] B. Liang, Q. Cao, J. G. Wang, and L. Jiang, "Experimental study on slaking characteristics of feeble disintegration soft rock in drying-wetting cycle," China Safety Science Journal, vol. 27, pp. 92-96, 2017.

[14] Y. C. Guo, Q. Xie, and J. Q. Wen, "Laboratory test study on disinte-gration characteristics of red mudstone," Subgrade Engineering, pp. 53-55, 2008.

[15] M. Surendra, Additives to Control Slaking in Compacted Shales, pp. 161-165, Purdue university, West Lafayette, IN, USA, 1980.

[16] Y. Nara, K. Morimoto, and T. Yoneda, "Effects of humidity and temperature on subcritical crack growth in sandstone," International Journal of Solids and Structures, vol. 48, no. 7-8, pp. 1130-1140, 2011.

[17] M. J. Bailey, Shale Degradation and Other Parameters Related to the Construction of Compacted Embankments, pp. 76-23, Purdue University, West Lafayette, IN, USA, 1976, MSCE Thesis. 